\title{
Foreign Direct Investment Dynamics in Hungary
}

\author{
Kunofiwa Tsaurai \\ University of South Africa, Pretoria, South Africa \\ tsaurk@unisa.ac.za, kunofiwa.tsaurai@gmail.com
}

\begin{abstract}
The study discussed the dynamics of FDI in Hungary during the period from 1991 to 2015. The impact of FDI, FDI trends and determinants of FDI in Hungary were discussed. Empirical literature observed that FDI positively influenced economic growth in Hungary through boosting human capital development levels, total factor productivity, economic transformation, innovation, research and development, additional capital in the economy, modern technology, increased volume of additional capital and technology transfer. The study also revealed that most of the net FDI inflow into Hungary originated from developed countries and the least FDI net inflow came from transitional economies during the period under study. The general trend of FDI net inflow into Hungary followed a mixed pattern, with some years experiencing a positive net FDI inflow whilst other years were characterised by negative net FDI inflows. What is clear however is that FDI net inflow was consistently positive and experienced a positive growth following the integration of Hungary into the EU bloc of countries? The accession of Hungary into the EU removed barriers for the movement of capital, people, goods and services within the EU, reduced the cost of doing business and improved trade openness. These are the key locational advantages of FDI which improved FDI inflow into Hungary for a sustained period of time after the EU accession. The study also empirically tested the determinants of FDI in Hungary using the OLS multiple regression model with data ranging from 1991 to 2015. In contradiction to most previous studies on the subject matter, trade openness and financial development were found to have had a negative influence on FDI. The study also observed that inflation had a positive influence on FDI, contrary to Sayek (2009) who revealed that higher inflation levels erodes the foreign investors' profits, thereby making the host country not an attractive investment destination. However, exchange rate, education and economic growth had a positive but non-significant impact on FDI in Hungary, consistent to both theoretical and empirical literature. The implication of the study is that the Hungarian authorities are urged to design and implement policies aimed at improving education and economic growth in order to attract more FDI. Practical steps need to be taken by the Hungarian authorities in making sure that the value of the local currency is not overvalued and that trade openness is controlled and managed so that it does not reach a point where it begins to negatively affect FDI inflows.
\end{abstract}

Keywords: FDI; Growth; Determinants; Hungary; Eastern Europe

\section{Introduction}

According to Pilarska and Walega (2014), the inflow of FDI into Central and Eastern European countries, in particular Hungary is quite linked to the economic transformation witnessed since the integration with the European Union. This is consistent with an observation by UNCTAD (2012)which noted that international capital flow is an integral part of economic growth and development in the host countries.Although quite a number of studies which examines FDI in Central and Eastern European countries were done, those that exclusively focused on Hungary and are conclusive are very scant. Majority of studies on FDI in Hungary either used a case study approach or an empirical investigation. This study departs from previous studies in that it uses a case study approach and literature review approach to investigate the dynamics of FDI in Hungary. This study explores in greater detail the impact of FDI, the determinants of FDI and the trends of FDI (1991-2015) in Hungary using both case study and empirical literature review approaches. The fact that the author employed two different methodologies in one paper makes this study quite unique from previous ones done on a similar subject matter. The results from this study are expected to inform the Hungarian authorities how best they can package FDI related policies in order to stimulate economic growth in Hungary. This involves the environment which the Hungarian policymakers should strive to put in place in order to scale up FDI inflow activities that guarantee growth in the economy. The rest of the paper is structured as follows: Part 2 discusses the impact of FDI inflows into Hungary, part 3 presents the trends of FDI in Hungary whilst part 4 investigates the determinants of FDI in Hungary from an empirical literature point of view. Part 5 is an empirical test of the determinants of FDI in Hungary. Part 6 concludes the study. 
Impact of Foreign direct investment inflow in Hungary: Theory on the impact of FDI in the host country was pioneered by Romer (1986), Lucas (1988), Calvo and Sanchez-Robles (2002), Kumar and Pradhan (2002) and Nath (2005), among others. They generally concur that economic growth requires capital injection and that FDI induces technology transfer, managerial expertise and technical know-how necessary for economic growth take off. They also agree that FDI improves capital accumulation and total factor productivity which helps host countries to sustain the growth of their economies.A number of empirical research work examined the role played by FDI in the Hungarian economy. For example, Sgard (2014) studied the relationship between FDI and productivity levels in the firms in Hungary using data from 1992 to 1999. The study found out that FDI had a substantial net positive impact on total factor productivity among Hungarian firms investigated. Moreover, the study revealed that FDI improved the rate of Hungarian economy's convergence towards the European Union's productivity levels. Hlavacek and Bal-Domanska (2016) observed that FDI was at the center of not only economic transformation but also economic growth acceleration in most Central and Eastern European countries which include Hungary, Czech Republic, Estonia, Lithuania, Latvia and Poland.

Lengyel and Leydesdorff (2015) studied the impact of FDI on innovation in Hungary. The finding was that FDI had an overwhelming positive influence not only on innovation but on the overall growth of Hungary's economic regions. Foreign owned companies in Hungary positively influenced synergies in the Hungary's regional innovation frameworks. The finding resonated with Inzelt (2000) whose study revealed that FDI was instrumental in speeding up the rate of transformation system of innovation and subsequently boosted economic growth in Hungary. Using log linear model and the Cobb-Douglas function, Torlak (2003) investigated the link between FDI and productivity in Central and Eastern European countries. The results pointed out that there was a very strong positive and significant correlation between FDI and productivity levels of firms in Hungary, Poland, Czech Republic, Bulgaria and Romania. Farkas (2000) also investigated the role played by FDI on innovation and research and development in Hungary. The study revealed that research and development and innovation relied more strongly on the inflow of FDI into Hungary during the period under study. It further found out that FDI provided the necessary additional capital to spearhead the implementation of innovative ideas through research and development in Hungary.

Benacek et al. (2000) studied the influence of FDI in Hungary, Poland and the Czech Republic using panel data analysis. Their study noted that the existence of foreign investors had to a larger extent boosted productivity levels and the growth of the economy in Hungary, Poland and Czech Republic. Andras (2014) examined the role FDI played in Hungary's food industry using data ranging from 1960 to 1990 . The finding was that the favourable natural conditions in Hungary and the modern technology used in bigger farms from foreign investors played a major and instrumental role in promoting the food industry in Hungary. Fifekova and Nemcova (2015) studied the influence of FDI on economic growth in V4 countries which include Hungary, Poland, Slovakia and Czech Republic during the pre and post EU accession periods. They found out that FDI improved the volume of total investment, boosted capital stock, increased total productivity levels and real GDP in all the V4 countries. FDI transferred technology which also helped to boost total factor productivity over and above bringing in the technical know-how, innovation, knowledge capital, managerial, marketing and administrative skills into the V4 countries (Fifekova and Nemcova, 2015:13). The findings were supported by Gunther (2002) whose study observed that FDI immensely contributed to the modernisation of the Hungarian industry through building modern manufacturing plants and escalating innovation, research and development.

\section{Foreign direct investment trends in Hungary}

FDI net inflow and economic growth trends in Hungary (US Billion Dollars): FDI net inflows (billions of US\$ dollars) were characterised by a mixed pattern whilst GDP experienced a consistent positive growth during the period from 1991 to 2015 (see Figure 1). FDI net inflows grew by 3.34\%, from US $\$ 1.46$ billion in 1991 to US $\$ 4.8$ billion in 1995 whilst GDP increased by $11.64 \%$ during the same time period (from US $\$ 34.65$ billion in 1991 to US\$46.29 billion in 1995). FDI net inflows then declined from US\$4.8 billion in 1995 to US $\$ 2.75$ billion in 2000 before experiencing a $5.76 \%$ increase to close the year 2005 at US $\$ 8.51$ billion. On the other hand, GDP marginally went up by $0.92 \%$, from US\$46.29 billion in 1995 to US\$47.21 billion in 2000 before further going up by $65.38 \%$ to end the year 2005 at US $\$ 112.59$ billion. The five-year period between 
2005 and 2010 saw FDI net inflows declining by a massive $29.44 \%$ to close the year 2010 at a negative US $\$ 20.93$ billion whilst GDP grew by $17.67 \%$ during the same period to end the year 2010 at US $\$ 130.26$ billion. Moreover, GDP negatively grew by $8.54 \%$, from US $\$ 130.26$ billion in 2010 to US $\$ 121.72$ billion in 2015 whilst FDI net inflows experienced a $20.02 \%$ rebound from a negative US $\$ 20.93$ billion in 2010 to end the year 2015 at a negative US $\$ 0.91$ billion.

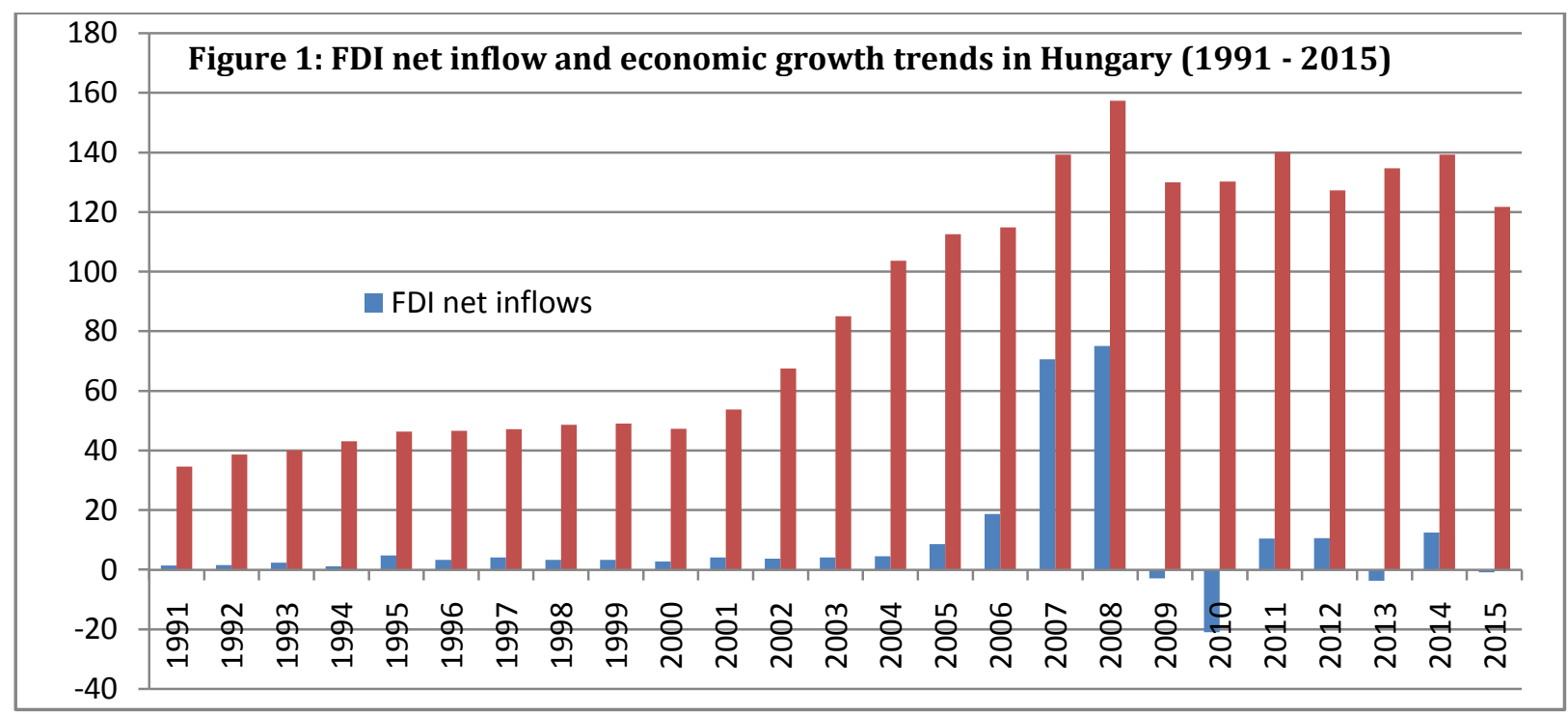

Source: World Bank (2015)

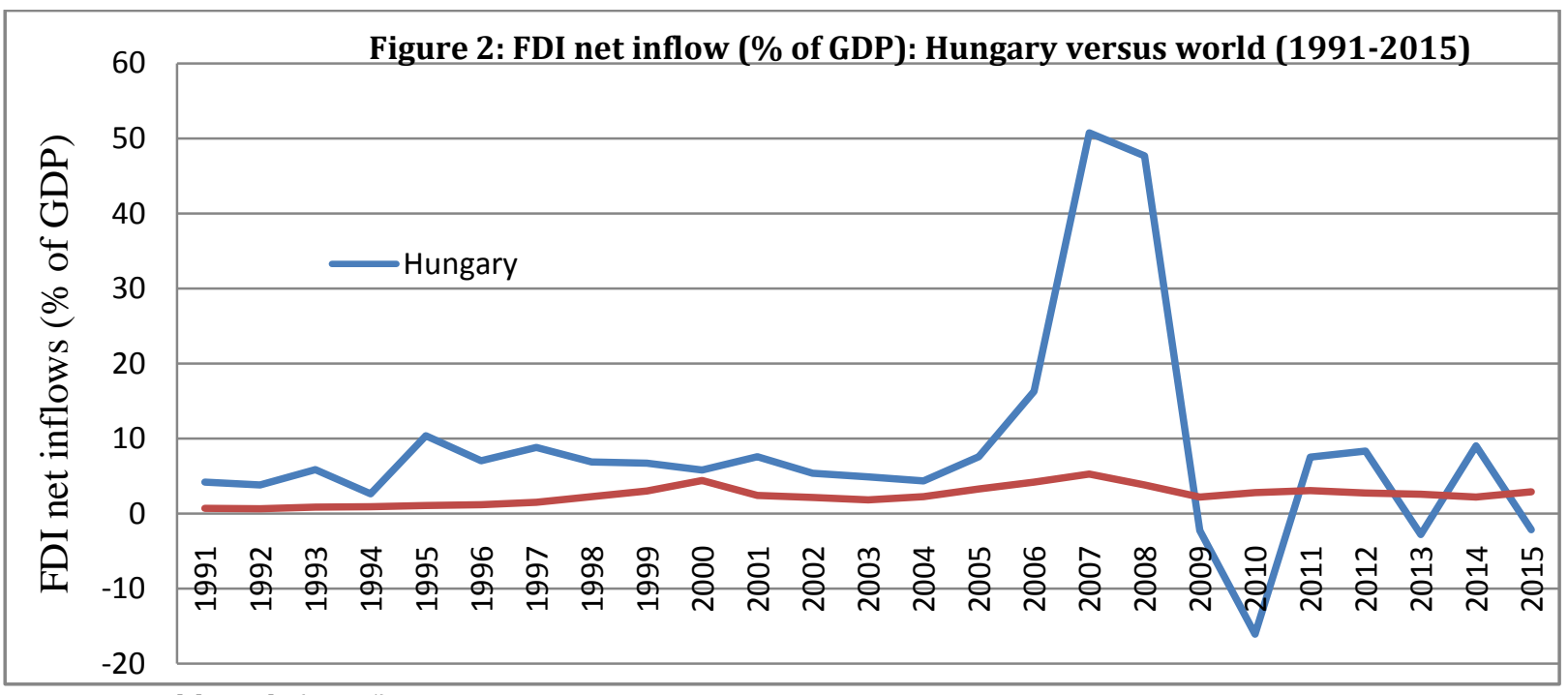

Source: World Bank (2015)

FDI net inflow as a share of GDP trends: Hungary versus the world: Figure 2 compare the FDI net inflows as a share of GDP for Hungary versus the entire world during the period from 1991 to 2015.FDI net inflows (\% of GDP) went up by 6.16 percentage points, from 4.22\% in 1991 to 10.38\% in 1995 in Hungary whereas the entire world experienced a 0.42 percentage points growth in FDI net inflow (\% of GDP) during the same time frame to end the year 1995 at $1.064 \%$. Whilst Hungary was characterised by a 4.56 percentage points decline in FDI net inflow (\% of GDP) during the five-year period between 1995 to 2000, the world experienced a 3.32 percentage points (from $1.064 \%$ in 1995 to $4.379 \%$ in 2000 ) positive growth in FDI net inflow (\% of GDP) during the same time frame. In addition, FDI net inflows (\% of GDP) increased by 1.73 percentage points, from 5.82\% in 2000 to $7.554 \%$ in 2005 in Hungary whereas FDI net inflow as a share of GDP for the entire world negatively grew by 1.15 percentage points during the same timeframe (from $4.379 \%$ 
in 2000 to $3.232 \%$ in 2005). Both Hungary and the entire world experienced a (1) negative growth in FDI net inflow as a share of GDP during the period from 2005 to 2010 and (2) a positive growth in FDI net inflow (\% of GDP) between 2010 to 2015. Specifically, Hungary was characterised by a massive 23.63 percentage points negative growth in FDI net inflows (\% of GDP), from $7.554 \%$ in 2005 to $-16.071 \%$ in 2010 before experiencing a positive growth by 13.92 percentage points during the subsequent five-year time period to close the year 2015 at $-2.156 \%$. On the other hand, the entire world saw FDI net inflow (\% of GDP) marginally declining by 0.49 percentage points, from $3.232 \%$ in 2005 to $2.743 \%$ in 2010 before experiencing an increase by 0.12 percentage points, from $2.743 \%$ in 2010 to $2.867 \%$ in 2015 .

Hungary FDI net inflow by geographical origin trends: A mixed pattern characterised the FDI net inflow into Hungary by geographical origin during the period between 2001 and 2012 (see Figure 3). In 2001, $88.03 \%$ of FDI net inflow into Hungary originated from developed countries whereas $1.6 \%, 0.58 \%$ and $9.78 \%$ of FDI net inflow into Hungary came from developing, transition and unspecified countries respectively.

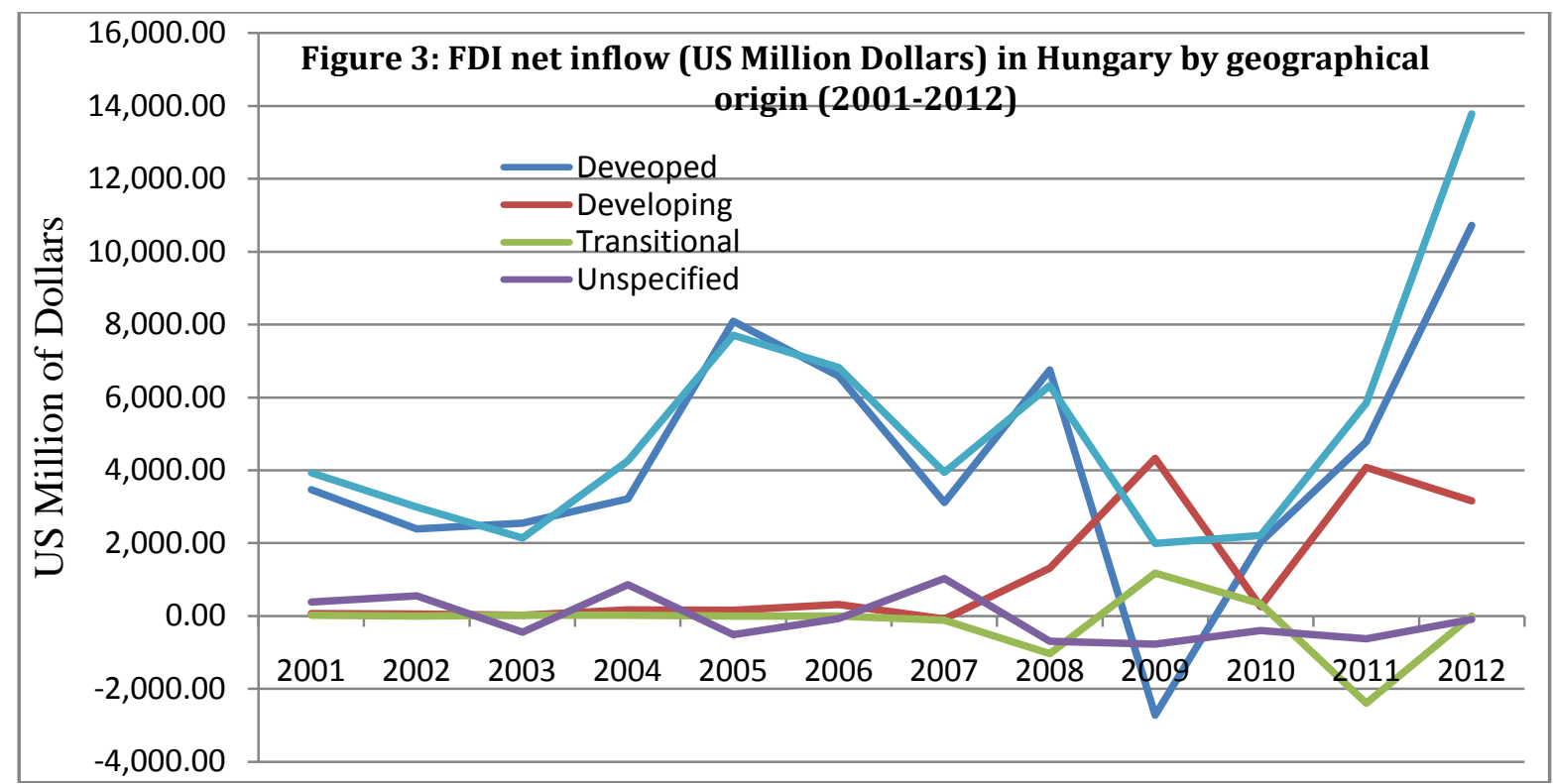

Source: UNCTAD FDI/TNC Database based on data from the Central Bank of Hungary

The net FDI inflow into Hungary that originated from developed countries in 2003 increased to $119.10 \%$ whilst the net FDI inflow into Hungary from developing and unspecified countries went down to $0.7 \%$ and $20.60 \%$ respectively. The net FDI inflow into Hungary that originated from transition economies went up from $0.58 \%$ in 2001 to $0.79 \%$ in 2003 . Moreover, Hungary's net FDI inflow that originated from developed countries went down by 14.22 percentage points, from $119.10 \%$ in 2003 to $104.88 \%$ in 2005 whereas the net FDI inflow into Hungary that came from developing, transition and unspecified countries was $1.92 \%,-0.08 \%$ and $-6.72 \%$ respectively. The period between 2005 and 2007 saw net FDI inflow into Hungary which came from developed going down by 25.97 percentage points, from $104.88 \%$ in 2007 to $78.91 \%$ in 2007 whereas net FDI inflow into Hungary that originated from developing countries declined from $1.92 \%$ in 2005 to a negative $2.20 \%$ in 2007. Moreover, net FDI inflow into Hungary that came from transition economies further plummeted from a negative $0.08 \%$ in 2005 to a negative $2.84 \%$ in 2007 whilst Hungary's net FDI inflow from unspecified countries rebounded from a negative $6.72 \%$ in 2005 to a positive $26.13 \%$ in 2007 . FDI net inflow into Hungary that originated from developed countries plummeted by a massive $136.35 \%$, from US\$3 117 million in 2007 to a negative US\$2 723 million in 2009 whereas Hungary's net FDI inflow from developing nations experienced a massive positive growth of $216.42 \%$, from a negative US\$87 million in 2007 to a positive US\$4 322 million in 2009. On the other hand, transition economies' contribution towards Hungary's net FDI inflow went up by 58.69\%, from a negative US\$112 million in 2007 to a positive US\$1 172 million in 2009 whilst the contribution from unspecified countries declined by 38.76\%, from US\$1 032 million in 2007 to a negative US\$774 million in 2009. 
The year 2011 saw the origin of net FDI inflow into Hungary being distributed as follows: 81.84\% (from developed countries), $69.71 \%$ (from developing countries), $40.86 \%$ (from transition countries) and -10.69 $\%$ ( from unspecified countries). Last but not least, net FDI inflow into Hungary grew by a further 77.79\%, from US\$4 783 million in 2011 to US\$10 717 million in 2012 whereas Hungary's net FDI inflow originating from developing countries went down by US\$915 million, from US\$4 074 in 2011 to US\$3 159 million in 2012. FDI net inflow into Hungary that came from transition economies improved from a negative US\$2 388 million in 2011 to a negative US\$3 million in 2012 whilst Hungary's net FDI inflow from unspecified nations also improved from -US\$624 million in 2011 to -US\$97 million in 2012.

FDI stock in Hungary, by geographical origin (US Million Dollars): Figure 4 shows that most FDI stock in Hungary between the period 2001 to 2012 originated from developed countries, followed by unspecified countries, then developing countries and lastly transitional countries.

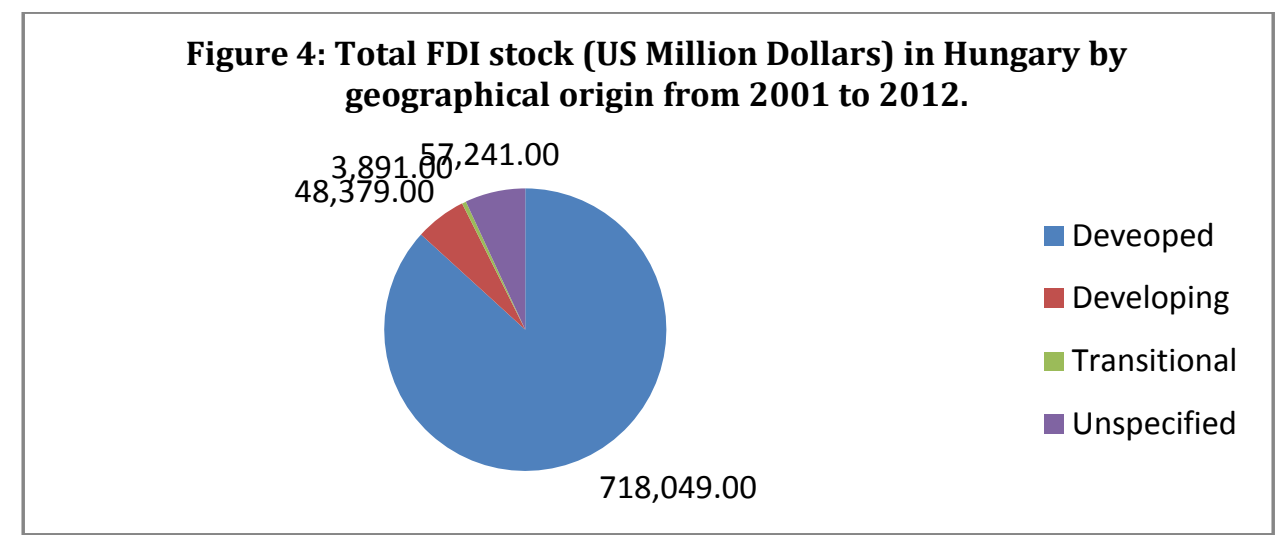

Source: UNCTAD FDI/TNC Database based on data from the Central Bank of Hungary

Specifically, the total FDI stock that originated from developed countries was US\$718 049 million, US\$57 241 million (unspecified), US\$48 379 million (developing) and US\$3 891 (transitional) between the year 2001 and 2012 (refer to Figure 4 and 5).

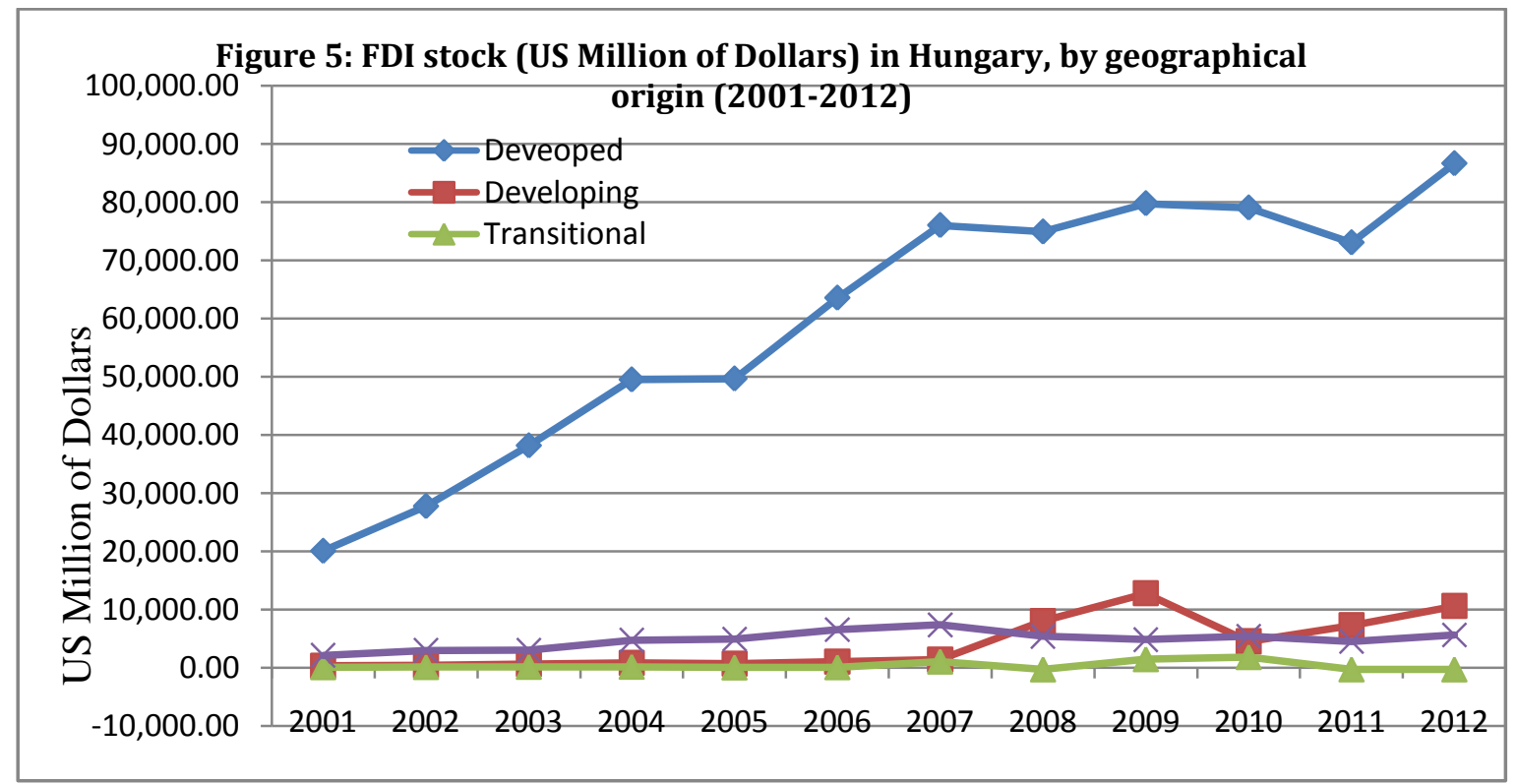

Source: UNCTAD FDI/TNC Database based on data from the Central Bank of Hungary 


\section{Determinants of foreign direct investment in Hungary-Empirical literature}

It is imperative to clarify the motives for FDI in order to be able to explain the differences in the FDI inflow into various host countries or locations. Dunning (1993) identified four broad motives for FDI, namely strategic asset, efficiency, market and resource seeking motives. Strategic asset seekers were defined as the multinational enterprises (MNEs) which consider FDI to promote or enhance their international competitiveness while efficiency seekers engage in FDI in order to rationalise their operational activities, enjoy the benefits of large economies of scale and take advantage of varying cost of factor endowments between and across countries. MNEs which are market seekers are driven by four main reasons. Firstly, to ensure they are physically present in prominent international markets in which their competitors operate. Secondly, to reduce costs of serving a local market through operating from a local facility. Thirdly, to follow customers or suppliers who might have relocated or expanded into other countries. Fourthly and lastly, to easily and quickly adapt its products to ever changing local tastes and this can be effectively managed through ensuring presence in the local market. Resource seeking MNEs invest in other countries in order to take advantage of the availability of resources or cheaper resources which include labour, physical resources, technology and expertise. Dunning (1993) observed that the resource and market seeking motives normally trigger initial FDI whilst strategic asset and efficiency seeking motives explains the subsequent FDI.

Markusen (1995) noted that vertically expanding MNEs may want to set up production facilities in other countries in order to cut the overall costs (efficiency seeking motive) whilst replicating production in foreign countries may put the MNE in a better position to access foreign markets (market seeking motive). In Hungary and Greece, market, efficiency and resource seeking were found to be the first, second and third order motives for FDI inflow respectively (Bitzenis et al., 2007:28). On the other hand, Tatoglu and Glaister (1998:219) showed that market development and faster access to new markets were the highest ranked motives for FDI in Hungary and Turkey. A number of empirical studies have investigated the determinants of FDI in Hungary and in other Central and Eastern European countries. Table 1 shows the factors that influenced foreign investment inflow into Hungary in their ranking order during the period from 2008 to 2012.

\section{Table 1: Hungary's indicators' ranking of foreign investment attractiveness}

\begin{tabular}{llllll}
\hline & $\mathbf{2 0 0 8}$ & $\mathbf{2 0 0 9}$ & $\mathbf{2 0 1 0}$ & $\mathbf{2 0 1 1}$ & $\mathbf{2 0 1 2}$ \\
\hline Overall competitiveness & 38 & 45 & 42 & 47 & 45 \\
Economic performance & 39 & 33 & 40 & 44 & 35 \\
Government efficiency & 47 & 50 & 51 & 52 & 51 \\
Business efficiency & 45 & 52 & 47 & 50 & 49 \\
Infrastructure & 27 & 33 & 35 & 35 & 35 \\
\hline
\end{tabular}

Source: www.worldcompetitiveness.com

According to the world competitiveness statistics in Table 1, the influence of economic performance on FDI inflow into Hungary increased from 2008 to 2009, declined in 2010, further deteriorated in 2011 before improving in year 2012. The impact of infrastructural development and government efficiency on FDI inflow into Hungary consistently decreased from 2008 to 2012. Moreover, the ranking of business efficiency as a determinant of FDI inflow went down from 45 in 2008 to 52 in 2009 before improving to 47 in 2010. It further declined to 50 in the year 2011 before improving by one rank to 49 in year 2012. Tarro and Kramli (2013) examined the variables that determined FDI in Hungary. Their study noted that factors such as economic growth, market size and the political, social and the legal environment were quite instrumental in promoting FDI in Hungary. Benacek et al. (2000) explored the FDI determinants in Hungary, Poland and the Czech Republic using panel data analysis. In support of the market size hypothesis, market size was found to be an instrumental variable that drove FDI inflows into Hungary, Poland and Czech Republic during the period under study. According to Pilarska and Walega (2014), attractive market conditions, low transaction costs emanating from the European Union (EU) integration, economic growth and low levels of investment risk were the three dominant factors which attracted FDI into Hungary and other Central and Eastern European countries between 1996 and 2012. The EU integration removed the internal barriers to the free movement of people, capital, goods and services which in turn significantly lowered down the transaction 
costs of doing business in the host countries. This greatly improved the locational advantage of FDI (Pilarska and Walega (2014:1170).

Ceka et al. (2014) investigated the determinants of FDI in Hungary, Bulgaria and Romania using the least squares method with World Bank extracted data ranging from 2000 to 2013. Their study found out that economic growth and the macro-economic environment positively and significantly influenced FDI into Hungary. On the other hand, Wang and Swain (1997) observed that market size, low cost of capital and political stability, low labour cost and a depreciated local currency were the key locational advantages of FDI in both Hungary and China. Employing ordinary least squares (OLS), multiple regression models, Torrisi (2015) examined the determinants of FDI in Hungary and Slovakia with data ranging from 1993 to 2012. Lower labour costs, trade openness, overall liberalization of the economy; low tax rates and economic integration with the EU were the major factors that attracted FDI into Hungary and Slovakia during the period under study (Torrisi, 2015:9).

\section{An Empirical Test of the FDI Determinants in Hungary}

Ordinary least squares (OLS) multiple regression model with annual time series secondary data ranging from 1991 to 2015 was used to estimate the determinants of FDI in Hungary. The sources of secondary include World development indicators, Global financial indicators, African development indicators, international financial statistics, International monetary fund and United Nations Development Programme (UNDP) databases and reports. Consistent with section 4 of this paper and other literature, the determinants of FDI can be summarised in the form of equation 1 (general model specification).

$\mathrm{FDI}=\mathrm{f}($ Trade openness. Inflation, economic growth, financial development, education, exchange rate)

The multiple ordinary least squares (OLS) model that was used to estimate the determinants of FDI in Hungary appears as follows:

$\mathrm{FDI}_{\mathrm{i}}=\alpha+\beta_{1} \mathrm{X}_{1 \mathrm{i}}+\beta_{2} \mathrm{X}_{2 \mathrm{i}}+\beta_{3} \mathrm{X}_{3 \mathrm{i}}+\beta_{4} \mathrm{X}_{4 \mathrm{i}}+\beta_{5} \mathrm{X}_{5 \mathrm{i}}+\beta_{6} \mathrm{X}_{6 \mathrm{i}}+\mathrm{u}_{\mathrm{i}}[2]$

Table 2: Variables, a priori expectation and theory intuition

\begin{tabular}{|c|c|c|}
\hline Variable & Theory intuition & Expected sign \\
\hline $\begin{array}{l}\text { Trade } \\
\text { openness }\end{array}$ & $\begin{array}{l}\text { Denisia (2010) noted that higher trade openness is a favourable } \\
\text { government policy that attracts FDI. Due to the resultant stiff } \\
\text { competition, trade openness crowds out local firms and economic } \\
\text { growth, a business climatic condition that is not favourable to FDI } \\
\text { (Baltagi et al., 2009). }\end{array}$ & $+/-$ \\
\hline Inflation & $\begin{array}{l}\text { Sayek (2009) argued that higher levels of inflation in the host country } \\
\text { chase away foreign investors as it erodes the amount of profits they } \\
\text { would have generated. }\end{array}$ & - \\
\hline $\begin{array}{l}\text { Economic } \\
\text { growth }\end{array}$ & $\begin{array}{l}\text { Jorgenson (1963) observed that higher levels of GDP or market size } \\
\text { positively influence the amount of FDI inflow into the host country. }\end{array}$ & + \\
\hline $\begin{array}{l}\text { Financial } \\
\text { development }\end{array}$ & $\begin{array}{l}\text { Bartels et al. (2009) observed that higher levels of financial } \\
\text { development are more able to attract FDI through its ability to reduce } \\
\text { transaction costs and ease the flow of information. In a well-developed } \\
\text { financial system environment, foreign investors may opt for portfolio } \\
\text { investment which then crowds out FDI (Hailu, 2010:109). }\end{array}$ & $+/-$ \\
\hline Education & $\begin{array}{l}\text { High levels of education or human capital development allows } \\
\text { companies to easily be able to utilize new technology that comes along } \\
\text { with FDI (Craigwell, 2012). }\end{array}$ & + \\
\hline $\begin{array}{l}\text { Exchange } \\
\text { rate }\end{array}$ & $\begin{array}{l}\text { Aliber (1970) noted that strong currencies stifle FDI whilst weak } \\
\text { currencies attract FDI. Countries which are characterized by strong } \\
\text { currencies are attracted to invest in countries whose currencies are } \\
\text { weak (Moosa, 2010). }\end{array}$ & $+/-$ \\
\hline
\end{tabular}

Source: Author compilation 
Where FDI is foreign direct investment, $\mathrm{X}_{1}$ stands for trade openness, $\mathrm{X}_{2}$ is inflation, $\mathrm{X}_{3}$ is economic growth, $\mathrm{X}_{4}$ is financial development, $X_{5}$ is education, $X_{6}$ represents exchange rate. $u_{i} i s$ the error term, $\alpha$ stands for the intercept whereas $\beta_{1}, \beta_{2}$ up to $\beta_{3}$ represents the coefficients of trade openness, inflation, growth, financial development, education and exchange rate respectively. To a larger extent, the choice of variables included in equation 2 was influenced by: (1) similar empirical studies on the subject matter (Giner and Giner. 2004; Sridharan et al., 2009; Vijayakumar et al., 2010; Branco. 2015; Pan. 2003; Kaur et al., 2013) and section 4 of this paper and (2) data availability. Exports of goods and services (\% of GDP), inflation, consumer prices (annual \%), GDP per capita, domestic credit provided by the financial sector (\% of GDP), total education expenditure by government (\% of GDP), exchange rate (local currency/US\$) respectively were used as measures for trade openness, inflation, economic growth, financial development, education and exchange rate, in line with majority of the prior studies on a similar subject matter. Table 2 shows the theoretical relationship between FDI and the independent variables shown in equation 1.The results of the OLS multiple regression model are summarised in Table 3.

Table 3: OLS multiple regression model results

\begin{tabular}{lllll}
\hline Variable & Co-efficient & Standard Error & T-statistic & Probability \\
\hline Trade openness & -0.1643 & 0.9982 & -0.1646 & 0.8711 \\
Inflation & 1.9940 & 1.2103 & 1.6475 & 0.1168 \\
Economic growth & 0.0050 & 0.0041 & 1.1956 & 0.2474 \\
Financial development & -0.7884 & 0.6123 & -1.2878 & 0.2141 \\
Education & 1.7846 & 1.9538 & 0.9134 & 0.3731 \\
Exchange rate & 0.0050 & 0.3107 & 0.0161 & 0.9873 \\
\hline
\end{tabular}

*/**/** indicate $10 \% / 5 \% / 1 \%$ respectively

Trade openness negatively influenced FDI in line with Baltagi et al. (2009) whose study argued thattrade openness crowds out local firms and economic growth, a business climatic condition that is opposite the dictates of the eclectic paradigm hypothesis and not favourable to FDI. Economic growth, exchange rate and education had a positive but non-significant impact on FDI, consistent with theoretical and empirical literature. Contrary to theory (Table 2), inflation positively but insignificantly influenced FDI in Hungary. The possible explanation is that higher inflation could have possibly led to the depreciation of the location currency which then attracted FDI into the Hungarian economy. On the other hand, financial development negatively but insignificantly affected FDI in Hungary, in line with Hailu (2010), who argued that in an environment in which financial development is high, foreign investors might opt for portfolio investment thus crowding out FDI.

\section{Conclusion}

The study discussed the dynamics of FDI in Hungary during the period from 1991 to 2015. The impact of FDI, FDI trends and determinants of FDI in Hungary were discussed. Empirical literature observed that FDI positively influenced economic growth in Hungary through boosting human capital development levels, total factor productivity, economic transformation, innovation, research and development, additional capital in the economy, modern technology, increased volume of additional capital and technology transfer. The study also revealed that most of the net FDI inflow into Hungary originated from developed countries and the least FDI net inflow came from transitional economies during the period under study. The general trend of FDI net inflow into Hungary followed a mixed pattern, with some years experiencing a positive net FDI inflow whilst other years were characterised by negative net FDI inflows. What is clear however is that FDI net inflow was consistently positive and experienced a positive growth following the integration of Hungary into the EU bloc of countries. The accession of Hungary into the EU removed barriers for the movement of capital, people, goods and services within the EU, reduced the cost of doing business and improved trade openness. These are the key locational advantages of FDI which improved FDI inflow into Hungary for a sustained period of time after the EU accession.The study also empirically tested the determinants of FDI in Hungary using the OLS multiple regression model with data ranging from 1991 to 2015. In contradiction to most previous studies on the subject matter, trade openness and financial development were found to have had a negative influence on FDI. The study also observed that inflation had a positive influence on FDI, contrary to Sayek (2009) who revealed that higher inflation levels erodes the foreign investors' profits, thereby making the host country not 
an attractive investment destination. However, exchange rate, education and economic growth had a positive but non-significant impact on FDI in Hungary, consistent to both theoretical and empirical literature (refer to Table 2). The implication of the study is that the Hungarian authorities are urged to design and implement policies aimed at improving education and economic growth in order to attract more FDI. Practical steps need to be taken by the Hungarian authorities in making sure that the value of the local currency is not overvalued and that trade openness is controlled and managed so that it does not reach a point where it begins to negatively affect FDI inflows.

\section{References}

Aliber, R. Z. (1970). A theory of direct foreign investment. The International Corporation, 3, 17-34.

Andras, S. (2014). Foreign direct investment in food industry in Hungary. International Journal of Business and Management Studies, 3(3), 285-296.

Baltagi, B. H., Demitriades, P. O. \& Law, S.H. (2009). Financial development, openness and institutions: Evidence from panel data. Journal of Development Economics, 89(2), 285-296.

Bartels, F. L., Alladina, S. N. \& Lederer, S. (2009). Foreign direct investment in Sub-Saharan Africa: Motivating factors and policy issues. Journal of African Business, 10(2), 141-162.

Benacek, V., Gronicki, M., Holland, D. \& Sass, M. (2000). The determinants and impact of foreign direct investment in Central and Eastern Europe: A comparison of survey and econometric evidence: Transnational Corporations, Journal of United Nations, 9(3), 163-212.

Bitzenis, A., Tsitouras, A. \& Vlachos, V.A. (2007). Motives for FDI in a small EMU member state: A case of Greece. Journal of Economics and Business, 10(2), 11-42.

Branco, R. C. (2015). The BRICS: Some historical experiences, growth challenges and opportunities. Fundacao Getulio Vargas, Centre for Growth and Economic Development, 1-26.

Calvo, M. B. \& Sanchez-Robles, B. (2002). Foreign direct investment, Economic freedom and Economic growth: New evidence from Latin America. Universidad de Cartabria, Economics Working Paper No. $4 / 03$.

Ceka, L. C., Sarbu, M. R. \& Cuza, A. L. (2014). Determinants of foreign direct investment and their relevance in decision making process. Economy and Management, 3(5), 577-584.

Craigwell, M. F. A. W. R. (2012). Economic growth, foreign direct investment and corruption in developed and developing countries. Journal of Economic Studies, 39(6), 639-652.

Denisia, V. (2010). Foreign direct investment theories: An overview of the main theories. European Journal of Interdisciplinary Studies, 2(2), 104-110.

Dunning, J. H. (1993). Foreign privatisation in Central and Eastern Europe. Ljubljana, Slovenia: Central and Eastern European Privatisation Network.

Farkas, P. (2000). The effects of foreign direct investment on R \& D and innovation in Hungary. Institute for World Economics. Hungarian Academy of sciences. Working Paper Series No. 108.

Fifekova, E. \& Nemcova, E. (2015). Impact of FDI on economic growth: Evidence from V4 countries. Periodica Polytechnica Social and Management, 23(1), 7-14.

Giner, J. M. \& Giner, G. (2004). An interpretative model of foreign direct investment in China: An economic policy approach. China Economic Review, 15(3), 268-280.

Gunther, J. (2002). FDI as a multiplier of modern technology in Hungarian industry. Intereconomics, September/(October), 263-269.

Hailu, Z. A. (2010). Demand side factors affecting the inflow of foreign direct investment to African countries: Does capital market matter? International Journal of Business and Management, 5(5), 103-112.

Hlavacek, P. \& Bal-Domanska. B. (2016). Impact of foreign direct investment on economic growth in Central and Eastern European countries. Engineering Economics, 27(3), 21-33.

Inzelt, A. (2000). Foreign direct investment in R \& D: Skin-deep and soul-deep cooperation. Science and Public Policy, 27(4), 241-251.

Jorgenson, D.W. (1963). Capital theory and investment behaviour. The American Economic Review, 53(2), 247259.

Kaur, M., Yadav, S. S. \& Gautam, V. (2013). Financial system development and foreign direct investment: A panel data study for BRIC countries. Global Business Review, 14(4), 729-742. 
Kumar, N. \& Pradhan, J. P. (2002). FDI, externalities and economic growth in developing countries: Some empirical explorations and implications for WTO negotiations on investment. RIS Discussion Paper No. 27/2002. New Delhi, India.

Lengyel, B. \& Leydesdorff, L. (2015). The effects of FDI on innovation systems in Hungarian regions: Where is the synergy generated? MPRA Munich Personal RePEc Archive. Centre of Economic and Regional Studies, Hungarian Academy of Sciences, Amsterdam School of Communication Research, University of Amsterdam.

Lucas, R. (1988). On the mechanics of economic development. Journal of Monetary Economics, 22(1), 3-42.

Markusen, J. (1995). The boundary of multinational enterprises and the theories of international trade. Journal of Economic Perspectives, 9(2), 169-189.

Moosa, I. A. (2010). International finance: An analytical approach. McGraw Hill Australia Pty Ltd, $3^{\text {rd }}$ edition.

Nath, H. (2005). Trade, Foreign direct investment and growth: Evidence from transition economies. SHSU Economics and International Business Working paper No. SHSU-Eco-WP05-04. Huntsville, TX: Sam Houston State University.

Pan, Y. (2003). The inflow of foreign direct investment to China: The impact of country specific factors. Journal of Business Research, 56(10), 829-833.

Pilarska, C. \& Walega, G. (2014). Determinants of FDI inflows to Poland, Czech Republic and Hungary in context of integration into European Union. The $8^{\text {th }}$ International days of statistics and Economics, Pragues, 11(13), 1167-1177.

Romer, P. (1986). Increasing returns and long run economic growth. Journal of Political Economy, 94(5), $1002-1037$.

Sayek, S. (2009). Foreign direct investment inflation. Southern Economic Journal, 76(2), 419-443.

Sgard, J. (2014). Direct foreign investments and productivity growth in Hungarian firms, 1992-1999. HAL archives-ouvertes.

Sridharan, P., Vijayakumar, N. \& Chandra, S. R. K. (2009). Causal relationship between foreign direct investment and growth: Evidence from BRICS countries. International Business Research, 2(4), 198203.

Tarro, A. \& Kramli, A. (2013). Analysis about Hungary's attractiveness to investors with particular regard to foreign direct investment. Regional Growth, Development and Competitiveness. University of Szeged, Doctoral School in Economics, 101-113.

Tatoglu, E. \& Glaister, K.W. (1998). An analysis of motives for western FDI in Turkey. International Business Review, 7(2), 203-230.

Torlak, E. (2003). Foreign direct investment, technology transfer and productivity growth: Empirical evidence for Hungary, Poland, Romania, Bulgaria and Czech Republic. Hamburg Institute of International Economics, Germany.

Torrisi, C. R. (2015). FDI in Hungary and Slovakia: The experience of smaller EU economies. Journal of Finance and Accountancy, 20, 1-10.

UNCTAD. (2012). World Investment Report. New York: United Nations.

Vijayakumar, N., Sridharan, P. \& Rao, K. C. S. (2010). Determinants of FDI in BRICS countries: A panel data analysis. International Journal of Business, Science and Applied Management, 5(3), 1-13.

Wang, Z. Q. \& Swain, N. (1997). Determinants of inflow of foreign direct investment in Hungary and China: Time series approach. Journal of International Development, 9(5), 695-726.

World Bank. (2015). World Development Indicators published by the World Bank, Washington D.C. 